\title{
Activity of the grain aphid (Sitobion avenae) and the bird cherry-oat aphid (Rhopalosiphum padi) during the feeding behaviour on an artificial diet containing extracts of surface waxes
}

\author{
Aktywność mszycy zbożowej (Sitobion avenae) \\ oraz czeremchowo-zbożowej (Rhopalosiphum padi) w procesie żerowania \\ mszyc na sztucznych pożywkach z ekstraktami wosków powierzchniowych
}

\author{
Agnieszka Wójcicka*
}

\begin{abstract}
Summary
Electrical Penetration Graphs (EPG) were used to monitor the feeding behaviour of cereal aphids exposed to the surface waxes in artificial diets. The EPG patterns generated by aphids feeding on plants were used to interpret the patterns generated on the artificial diets. The surface waxes from waxy genotype (RAH 122) completely stopped salivation (as indicated by EPG pattern p-E1), passive and active ingestion (as indicated by pattern $p-E 2$ and pattern $p-G$ ) and also delayed the onset of stylet activity (EPG pattern $p-C$ ). The surface waxes from waxless genotype (RAH 366) applied into the artificial diets prolonged the period of stylet activity in the diet (pattern $p-C$ ), passive ingestion of the diet (pattern $p$-E2), reduced non-probing (pattern p-np) and active ingestion of the diet (pattern $\mathrm{p}-\mathrm{G}$ ). Results presented in the paper suggest that chemical compounds which occur within epicuticular waxes of the waxy genotype (RAH 122) and waxless genotype (RAH 366) play an important role during feeding behaviour of the grain aphid and bird cherry-oat aphid. Summing up the epicuticular wax compounds clearly affected feeding behavior of the cereal aphids, thus waxy triticale genotype might be useful for limiting the population of cereal pest.
\end{abstract}

Key words: waxes; triticale; aphids; artificial diet; EPG

\begin{abstract}
Streszczenie
Do zbadania aktywności wosków powierzchniowych w procesie żerowania mszyc zbożowych na sztucznych pożywkach zastosowano elektroniczny monitoring nakłuwania tkanek roślinnych (EPG - Electrical Penetration Graphs). Modele EPG obserwowane podczas żerowania mszyc na roślinach użyto do interpretacji aktywności mszyc obserwowanych podczas żerowania na sztucznych pożywkach. Woski powierzchniowe pochodzące z silnie woskowego genotypu (RAH 122) całkowicie hamowały wydzielanie śliny (jak wykazał model p-E1), pasywne i aktywne pobieranie diety (jak wykazał model p-E2 i model p-G) i opóźniały pierwsze nakłucie (model p-C). Woski powierzchniowe z genotypu RAH 366, wprowadzone do sztucznej pożywki wydłużały okres aktywności sztyletów w pożywce (model $\mathrm{p}-\mathrm{C}$ ), pasywne pobieranie pożywki (model E2), redukowały okres braku penetracji (model p-np) i aktywne pobieranie pożywki (model $\mathrm{p}-\mathrm{G}$ ). Wyniki prezentowane w pracy wskazują, że chemiczne komponenty wosku epikutykularnego woskowego genotypu RAH 122 i słabo pokrytego woskiem genotypu RAH 366 pełnią ważną rolę w procesie żerowania obu badanych gatunków mszyc czyli mszycy zbożowej i czeremchowo-zbożowej. Komponenty epikutykularnych wosków wyraźnie oddziaływują na zachowanie mszyc zbożowych podczas żerowania, a woskowy genotyp pszenżyta może być użyty do ograniczania szkodliwych owadów.
\end{abstract}

Słowa kluczowe: woski; pszenżyto; mszyce; sztuczne pożywki; EPG

Uniwersytet Przyrodniczo-Humanistyczny w Siedlcach

Katedra Biochemii i Biologii Molekularnej w Instytucie Biologii

Prusa 12, 08-110 Siedlce

*corresponding author: agnieszkawojcicka4@wp.pl 


\section{Wstęp / Introduction}

Kutykula roślin lądowych kontaktująca się ze środowiskiem pokryta jest mieszaniną lipofilowych komponenttów określanych terminem woskowej powierzchni roślin (Koch i wsp. 2009; Athukorala i Mazza 2010; Ou i wsp. 2012; Mukhtar i wsp. 2014). Pełni ona szereg funkcji ekologicznych włączając w to interakcje owad-roślina (Rostás i wsp. 2008; Städler i Reifenrath 2009; Hilker i Meiners 2011; Yin i wsp. 2011; Prüm i wsp. 2012). Specyficzność struktur woskowych pokrywających powierzchnie roślin związana jest $\mathrm{z}$ ich składem chemicznym (Koch i wsp. 2009). Woski epikutykularne roślin są mieszaniną szeregu komponentów takich, jak cukry, aminokwasy oraz substancji należących do bloku metabolizmu wtórnego: glukozynolanów, furanokumaryn, alkaloidów, terpenoidów, flawonoidów oraz fenoli (Jetter i Schäffer 2001; Bargel i wsp. 2004; Schoonhoven i wsp. 2006; Fernández i wsp. 2011; Supapvanich i wsp. 2011). Intensywność występowania epikutykularnego wosku na roślinach może w sposób istotny wpływać na zachowanie i rozwój owadów (Nam i Hardie 2012). Wśród bogatej gamy substancji powierzchniowych znajdują się związki, które umożliwiają odnajdywanie pokarmu i rozpoczynanie żerowania oraz substancje działające odstraszająco na owady, stanowiące barierę zabezpieczającą roślinę przed ich atakiem (Huang i wsp. 2003; Reina-Pinto i Yephremov 2009).

Celem pracy było określenie wpływu substancji występujących na powierzchni pszenżyta ozimego na zachowanie mszycy zbożowej oraz czeremchowo-zbożowej podczas żerowania na sztucznych pożywkach. Badania przeprowadzono techniką elektronicznej rejestracji żerowania EPG (Electrical Penetration Graph technique).

\section{Materiały i metody / Materials and methods}

Badania wykonano na siewkach dwóch wyselekcjonowanych genotypów pszenżyta ozimego: RAH 122 (silny nalot woskowy) i RAH 366 (słaby nalot woskowy). Nasiona badanych roślin pochodziły z Instytutu Hodowli i Aklimatyzacji Roślin - Państwowego Instytutu Badawczego (IHAR - PIB) w Radzikowie koło Błonia pod Warszawą. Siewki wyhodowano w warunkach laboratoryjnych w komorze klimatyzacyjnej $\mathrm{w}$ temperaturze 20-25ำ przy fotoperiodzie $16 \mathrm{~h}$ światło i $8 \mathrm{~h}$ ciemność.

Badanymi gatunkami były mszyca zbożowa Sitobion avenae (Fabricius 1775) oraz czeremchowo-zbożowa Rhopalosiphum padi (Linnaeus 1758) (Hemiptera: Aphididae), hodowla była prowadzona w Uniwersytecie Przyrodniczo-Humanistycznym w Siedlcach.

Aktywność związków chemicznych obecnych w woskach epikutykularnych badanych roślin w procesie żerowania mszyc zbożowych, określono w etanolowych ekstraktach wykonanych z 25-dniowych siewek badanych genotypów pszenżyta. Ekstrakty przygotowano przez zanurzenie badanych roślin w etanolu. Czas ekstrakcji wynosił 20 s. Ekstrakty woskowe służyły do sporządzenia stężeń 10 i $100 \mu \mathrm{g} / \mathrm{g}$. Tak przygotowane ekstrakty wprowadzano do sztucznych, stałych pożywek, które stanowiły żele sacharozowo-agarozowe.
Żele wykonano mieszając $1,25 \%$ roztwór agarozy i $30 \%$ roztwór sacharozy. Całość ogrzewano w łaźni wodnej przez 10 minut, w temperaturze $70^{\circ} \mathrm{C}$. Do zawiesiny dodano ekstrakty wosków epikutykularnych o stężeniach 10 i $100 \mu \mathrm{g} / \mathrm{g}$ i przeniesiono na plastikowe pierścienie zaizolowane od spodniej strony Parafilmem. Po upływie 1-2 minut dochodziło do formowania żelu. Przygotowane w ten sposób bloki sacharozowo-agarozowe stanowiły podłoże do żerowania mszyc. Dodatkowo wykonano żele kontrolne, które nie zawierały ekstraktów woskowych.

Aktywność wosków epikutykularnych w procesie żerowania mszyc, zbadano metodą EPG (Leszczyński i Tjallingii 1994). Z kolonii macierzystej testowanych mszyc wybierano dorosłe, bezskrzydłe samice i umieszczano (przy pomocy pędzelka) na adaptorze próżniowym pod mikroskopem stereoskopowym. Następnie przy pomocy igły preparacyjnej na dorsalną stronę owada nanoszono kroplę srebrnej farby (Demetron L2027, Darmstadt, Germany) i zanurzano w niej mikroelektrodę (złoty drut o średnicy $20 \mu \mathrm{m}$ i długości $2 \mathrm{~cm}$ ). Po zaschnięciu farby redukowano próżnię w obwodzie adaptora i uwalniano owada. Dla każdego stężenia wosków epikutykularnych badanego genotypu wykonano w 10 powtórzeniach. Zapisu $4 \mathrm{~h}$ rejestracji zachowania się owadów oraz analizy danych dokonano za pomocą programu komputerowego STYLET 2.2. Modele EPG, których obecność stwierdzono podczas przeprowadzonych badań to: p-np, p-C, p-E1, p-E2 i p-G. Oznaczono je dodatkowo literą $p$ jako pierwszą literą wyrazu pożywka (p-pożywka). Do ich interpretacji użyto aktywności EPG obserwowanych podczas żerowania mszyc na roślinach (np, C, E1, E2, G), ponieważ aktywności owadów na dietach (Sauvion i wsp. 2004; Cid i Fereres 2010) są analogiczne do tych zidentyfikowanych i opisanych na roślinach (Tjallingii i Esch 1993; Tjallingii 1994; Zhang i wsp. 2009; Huang i wsp. 2012; Wu i wsp. 2013). Aktywność p-np oznacza, że sztylety owada znajdują się na zewnątrz pożywki, a w roślinie odpowiada obecności sztyletów na zewnątrz rośliny (model np.). Model p-C, odnosi się do aktywności sztyletów w diecie, natomiast $\mathrm{w}$ roślinie odpowiada penetracji sztyletów w elementach epidermy i mezofilu (model C). Aktywność p-E1, wskazuje na wydzielanie śliny do pożywki i odpowiada wydzielaniu śliny do elementów floemu w przypadku roślin (model E1). Aktywność p-E2 czyli pasywne pobieranie płynów $\mathrm{z}$ diety jest analogiczna do pasywnego pobierania soku floemowego z roślin (model E2). Aktywność $\mathrm{p}-\mathrm{G}$ to aktywne pobieranie płynów z diety, odpowiadająca aktywnemu pobieraniu ksylemu $\mathrm{z}$ roślin (model $\mathrm{G}$ ).

Istotność różnic pomiędzy wartościami badanych parametrów EPG dla mszyc żerujących na dietach kontrolnych i dietach z ekstraktami woskowymi pochodzącymi z badanych genotypów pszenżyta ozimego określono testem t-Studenta.

\section{Wyniki i dyskusja / Results and discussion}

Stwierdzono, że woski powierzchniowe pochodzące z roślin silnie woskowego genotypu RAH 122 wprowadzone do pożywek, na których żerowały badane gatunki 
Tabela 1. Wpływ wosków epikutykularnych na aktywność mszyc zbożowych podczas żerowania na sztucznych dietach

Table 1. Effect of the epicuticular waxes on cereal aphid activity while preying on the artificial diets

\begin{tabular}{l|c|c|c}
\hline \multirow{2}{*}{$\begin{array}{c}\text { Badane genotypy } \\
\text { Studied genotypes }\end{array}$} & \multicolumn{2}{c}{ Parametry EPG - EPG Parameters } \\
\cline { 2 - 4 } \multicolumn{2}{c|}{} & mszyca zbożowa - Sitobion avenae & mszyca czeremchowo-zbożowa - Rhopalosiphum padi \\
\hline Kontrola - Control & $10 \mu \mathrm{g} / \mathrm{g}$ & $\mathrm{C}, \mathrm{E} 1, \mathrm{E} 2, \mathrm{G}$ & $\mathrm{C}, \mathrm{E} 1, \mathrm{E} 2, \mathrm{G}$ \\
\hline \multirow{2}{*}{ RAH 122} & $100 \mu \mathrm{g} / \mathrm{g}$ & $\mathrm{C}$ & $\mathrm{C}$ \\
\hline \multirow{2}{*}{ RAH 366} & $10 \mu \mathrm{g} / \mathrm{g}$ & $\mathrm{C}$ & $\mathrm{C}$ \\
\cline { 2 - 4 } & $100 \mu \mathrm{g} / \mathrm{g}$ & $\mathrm{C}, \mathrm{E} 1, \mathrm{E} 2, \mathrm{G}$ & $\mathrm{C}, \mathrm{E} 1, \mathrm{E} 2, \mathrm{G}$ \\
\hline
\end{tabular}

EPG - Electrical Penetration Graph technique

Tabela 2. Wpływ stężenia wosków epikutykularnych na zachowanie mszycy zbożowej $S$. avenae podczas żerowania na sztucznych dietach

Table 2. Effect of different concentrations of the epicuticular waxes on feeding behaviour of the grain aphid S. avenae on the artificial diets

\begin{tabular}{l|c|c|c|c|c}
\hline \multirow{2}{*}{$\begin{array}{c}\text { Parametry EPG } \\
\text { EPG Parameters } \\
{[\%]}\end{array}$} & \multirow{2}{*}{$\begin{array}{c}\text { Kontrola } \\
\text { Control }\end{array}$} & \multicolumn{3}{|c}{ Radane genotypy - Studied genotypes } \\
\cline { 3 - 6 } & & \multicolumn{2}{|c}{ RAH 122} & \multicolumn{2}{c}{ RAH 366} \\
\cline { 3 - 6 } $\begin{array}{l}\text { Model Np } \\
\text { Pattern Np }\end{array}$ & $8,5 \pm 0,3$ & $33,4 \pm 1,2^{* *}$ & $44,7 \pm 1,4^{* *}$ & $3,6 \pm 0,1^{* *}$ & $3,1 \pm 0,1^{* *}$ \\
\hline $\begin{array}{l}\text { Model C } \\
\text { Pattern C }\end{array}$ & $31,1 \pm 1,1$ & $66,6 \pm 2,0^{* *}$ & $55,3 \pm 2,7^{* *}$ & $41,4 \pm 1,3^{*}$ & $35,9 \pm 1,2^{*}$ \\
\hline $\begin{array}{l}\text { Model E1 } \\
\text { Pattern E1 }\end{array}$ & $17,1 \pm 0,5$ & $0,0 \pm 0,0^{* *}$ & $0,0 \pm 0,0^{* *}$ & $13,0 \pm 0,4^{*}$ & $8,0 \pm 0,3^{* *}$ \\
\hline $\begin{array}{l}\text { Model E2 } \\
\text { Pattern E2 }\end{array}$ & $23,0 \pm 0,7$ & $0,0 \pm 0,0^{* *}$ & $0,0 \pm 0,0^{* *}$ & $34,0 \pm 1,2^{*}$ & $48,0 \pm 1,6^{* *}$ \\
\hline $\begin{array}{l}\text { Model G } \\
\text { Pattern G }\end{array}$ & $20,3 \pm 0,6$ & $0,0 \pm 0,0^{* *}$ & $0,0 \pm 0,0^{* *}$ & $8,0 \pm 0,1^{* *}$ & $5,0 \pm 0,2^{* *}$
\end{tabular}

Wartości oznaczone gwiazdkami różnią się istotnie od wartości kontrolnych: *p $<0,05 ; *$ p $<0,001$ (test t-Studenta)

Values followed by asterisks are significantly different from control values: ${ }^{*} \mathrm{p}<0.05 ; * \mathrm{p}<0.001$ (Student's t-test)

mszyc zbożowych, czyli mszyca zbożowa $S$. avenae oraz czeremchowo-zbożowa $R$. padi, całkowicie hamowały wydzielanie śliny (model p-E1) oraz pasywne (model p-E2) i aktywne pobieranie diety (model p-G). W przypadku obu badanych stężeń 10 i $100 \mu \mathrm{g} / \mathrm{g}$, podczas żerowania obu badanych gatunków mszyc, obserwowano jedynie aktywność świadczącą o penetracji podłoża (model p-C). Wprowadzeniu do pożywek ekstraktów woskowych pochodzących z roślin genotypu RAH 366 charakteryzującego się słabym nalotem woskowym, towarzyszyły wszystkie badane aktywności, które obserwowano na pożywkach kontrolnych: p-np, p-C, p-E1, p-E2 i p-G (tab. 1).

Procentowy udział badanych aktywności EPG wykazał, że dodanie do pożywek ekstraktów woskowych pochodzących z roślin silnie woskowego genotypu RAH 122 spowodowało znaczne wydłużenie czasu, kiedy sztylety mszycy zbożowej znajdowały się na powierzchni pożywki (model p-np) (tab. 2). W przypadku pożywek kontrolnych czas trwania tego modelu stanowił $8,5 \%-4 \mathrm{~h}$ rejestracji żerowania, a po dodaniu ekstraktu woskowego o stężeniu $10 \mu \mathrm{g} / \mathrm{g}$ wzrósł 4-krotnie i wyniósł $33,4 \%$, natomiast przy stężeniu $100 \mu \mathrm{g} / \mathrm{g}$ wzrósł 5-krotnie i osiągnął wartość $44,7 \%$. Ponadto aktywność p-C związana $\mathrm{z}$ penetracją podłoża, która w przypadku kontroli stanowiła $31,1 \%$, po dodaniu ekstraktu woskowego o niższym stężeniu wzrosła 2-krotnie do wartości $66,6 \%$, natomiast przy wyższym stężeniu do wartości 55,3\% (tab. 2). Dodanie ekstraktów woskowych spowodowało również wydłużenie czasu do pierwszego nakłucia (czas do pierwszej aktywności p-C), skróciło czas trwania pierwszej aktywności p-C oraz zwiększyło jej częstotliwość podczas całej $4 \mathrm{~h}$ rejestracji żerowania (tab. 3).

Po wprowadzeniu do pożywek ekstraktów woskowych z genotypu RAH 366 słabo pokrytego woskiem odnotowano spadek procentowego udziału aktywności p-np, aktywności p-E1 i p-G. Towarzyszył temu wzrost udziału aktywności sztyletów w diecie (p-C) oraz aktywności p-E2 związanej z pasywnym pobieraniem diety. W przypadku aktywności p-E2 przy stężenia $100 \mu \mathrm{g} / \mathrm{g}$ wzrost ten był 2-krotny wobec kontroli i wyniósł $48,0 \%$ (tab. 2). Na pożywkach z ekstraktami woskowymi z genotypu RAH 366 obserwowano również znaczne skrócenie czasu do pierwszego nakłucia, wydłużenie czasu trwania pierwszej aktywności p-C oraz spadek jej częstotliwości (tab. 3).

Dla mszycy czeremchowo-zbożowej analiza aktywności EPG wykazała, że dodanie do pożywek ekstraktów woskowych pochodzących $\mathrm{z}$ roślin silnie woskowego genotypu RAH 122 o stężeniu 10 i $100 \mu \mathrm{g} / \mathrm{g}$ wydłużyło 
Tabela 3. Zachowanie się mszycy zbożowej S. avenae podczas żerowania na sztucznych dietach

Table 3. The behaviour of the grain aphid S. avenae while feeding on the artificial diets

\begin{tabular}{|c|c|c|c|c|c|}
\hline \multirow{3}{*}{$\begin{array}{l}\text { Parametry EPG } \\
\text { EPG Parameters }\end{array}$} & \multirow{3}{*}{$\begin{array}{c}\text { Kontrola } \\
\text { Control }\end{array}$} & \multicolumn{4}{|c|}{ Badane genotypy - Studied genotypes } \\
\hline & & \multicolumn{2}{|c|}{ RAH 122} & \multicolumn{2}{|c|}{ RAH 366} \\
\hline & & $10 \mu \mathrm{g} / \mathrm{g}$ & $100 \mu \mathrm{g} / \mathrm{g}$ & $10 \mu \mathrm{g} / \mathrm{g}$ & $100 \mu \mathrm{g} / \mathrm{g}$ \\
\hline $\begin{array}{l}\text { Czas do pierwszego nakłucia } \\
\text { Time until first probing [min] }\end{array}$ & $4,1 \pm 0,1$ & $8,0 \pm 0,4^{*}$ & $10,0 \pm 0,1^{*}$ & $1,0 \pm 0,0^{*}$ & $0,8 \pm 0,0^{*}$ \\
\hline $\begin{array}{l}\text { Czas trwania pieszego modelu } C \\
\text { Duration of the first } C \text { pattern }\end{array}$ & $8,0 \pm 0,3$ & $4,9 \pm 0,1 *$ & $0,4 \pm 0,0^{*}$ & $10,0 \pm 0,7^{*}$ & $12,0 \pm 0,8^{*}$ \\
\hline $\begin{array}{l}\text { Częstotliwość aktywności } \mathrm{C} \\
\text { Frequency of } \mathrm{C} \text { activity }\end{array}$ & $4,2 \pm 0,0$ & $5,4 \pm 0,2 *$ & $8,2 \pm 0,4^{*}$ & $3,1 \pm 0,0^{*}$ & $2,1 \pm 0,1 *$ \\
\hline
\end{tabular}

Wartości oznaczone gwiazdkami różnią się istotnie od wartości kontrolnych: *p $<0,001$ (test t-Studenta)

Values followed by asterisks are significantly different from control values: ${ }^{*} \mathrm{p}<0.001$ (Student's t-test)

Tabela 4. Wpływ stężenia wosków epikutykularnych na zachowanie mszycy czeremchowo-zbożowej $R$. padi podczas żerowania na sztucznych dietach

Table 4. Effect of different concentrations of the epicuticular waxes on feeding behaviour of the bird cherry-oat aphid $R$. padi on the artificial diets

\begin{tabular}{|c|c|c|c|c|c|}
\hline \multirow{3}{*}{$\begin{array}{c}\text { Parametry EPG } \\
\text { EPG Parameters } \\
{[\%]}\end{array}$} & \multirow{3}{*}{$\begin{array}{c}\text { Kontrola } \\
\text { Control }\end{array}$} & \multicolumn{4}{|c|}{ Badane genotypy - Studied genotypes } \\
\hline & & \multicolumn{2}{|c|}{ RAH 122} & \multicolumn{2}{|c|}{ RAH 366} \\
\hline & & $10 \mu \mathrm{g} / \mathrm{g}$ & $100 \mu \mathrm{g} / \mathrm{g}$ & $10 \mu \mathrm{g} / \mathrm{g}$ & $100 \mu \mathrm{g} / \mathrm{g}$ \\
\hline $\begin{array}{l}\text { Model Np } \\
\text { Pattern Np }\end{array}$ & $12,0 \pm 0,4$ & $36,1 \pm 1,3 * *$ & $41,8 \pm 1,5^{* *}$ & $7,1 \pm 0,2^{* *}$ & $3,2 \pm 0,1^{* *}$ \\
\hline $\begin{array}{l}\text { Model C } \\
\text { Pattern C }\end{array}$ & $37,2 \pm 1,3$ & $63,9 \pm 2,2 * *$ & $58,2 \pm 2,0 * *$ & $53,0 \pm 1,9^{*}$ & $38,7 \pm 1,4 \mathrm{~ns}$ \\
\hline $\begin{array}{l}\text { Model E1 } \\
\text { Pattern E1 }\end{array}$ & $14,4 \pm 0,5$ & $0,0 \pm 0,0 * *$ & $0,0 \pm 0,0 * *$ & $10,0 \pm 0,3^{*}$ & $15,1 \pm 0,5^{* *}$ \\
\hline $\begin{array}{l}\text { Model E2 } \\
\text { Pattern E2 }\end{array}$ & $20,1 \pm 0,7$ & $0,0 \pm 0,0 * *$ & $0,0 \pm 0,0 * *$ & $27,5 \pm 1,0 *$ & $39,0 \pm 1,4^{* *}$ \\
\hline $\begin{array}{l}\text { Model G } \\
\text { Pattern G }\end{array}$ & $16,3 \pm 0,6$ & $0,0 \pm 0,0 * *$ & $0,0 \pm 0,0 * *$ & $2,3 \pm 0,1 * *$ & $4,0 \pm 0,1 * *$ \\
\hline
\end{tabular}

Wartości oznaczone gwiazdkami różnią się istotnie od wartości kontrolnych: *p $<0,05 ; * * p<0,001$; ns - nie istotne (test t-Studenta)

Values followed by asterisks are significantly different from control values: ${ }^{*} \mathrm{p}<0.05 ; * * \mathrm{p}<0.001$; ns - not significant (Student's t-test)

Tabela 5. Zachowanie się mszycy czeremchowo-zbożowej $R$. padi podczas żerowania na sztucznych dietach

Table 5. The behaviour of the bird cherry-oat aphid R. padi while feeding on the artificial diets

\begin{tabular}{l|c|c|c|c|c}
\hline \multirow{2}{*}{$\begin{array}{c}\text { Parametry EPG } \\
\text { EPG Parameters }\end{array}$} & \multirow{2}{*}{$\begin{array}{c}\text { Kontrola } \\
\text { Control }\end{array}$} & \multicolumn{3}{|c}{ RAH 122} & \multicolumn{3}{c}{ RAH 366} \\
\cline { 3 - 5 } & & $10 \mu \mathrm{g} / \mathrm{g}$ & $100 \mu \mathrm{g} / \mathrm{g}$ & $10 \mu \mathrm{g} / \mathrm{g}$ & $100 \mu \mathrm{g} / \mathrm{g}$ \\
\cline { 3 - 6 } $\begin{array}{l}\text { Czas do pierwszego nakłucia } \\
\text { Time until first probing [min] }\end{array}$ & $3,2 \pm 0,0$ & $9,0 \pm 0,0^{* *}$ & $13,0 \pm 0,6^{* *}$ & $1,5 \pm 0,3^{* *}$ & $1,3 \pm 0,2^{* *}$ \\
\hline $\begin{array}{l}\text { Czas trwania pieszego modelu C } \\
\text { Duration of the first C pattern }\end{array}$ & $5,7 \pm 0,1$ & $3,4 \pm 0,1^{*}$ & $0,4 \pm 0,0^{* *}$ & $8,0 \pm 0,9^{*}$ & $9,0 \pm 0,3^{*}$ \\
\hline $\begin{array}{l}\text { Częstotliwość aktywności C } \\
\text { Frequency of C activity }\end{array}$ & $4,8 \pm 0,2$ & $6,8 \pm 0,3^{*}$ & $10,3 \pm 0,7^{* *}$ & $3,5 \pm 0,0^{* *}$ & $2,3 \pm 0,2^{*}$ \\
\hline
\end{tabular}

Wartości oznaczone gwiazdkami różnią się istotnie od wartości kontrolnych: *p $<0,05^{* *} ; \mathrm{p}<0,001$ (test t-Studenta)

Values followed by asterisks are significantly different from control values: ${ }^{*} \mathrm{p}<0.05 ; * * \mathrm{p}<0.001$ (Student's t-test)

czas trwania modelu p-np, podczas którego sztylety mszyc nie dokonywały żadnych nakłuć (tab. 4). W przypadku pożywek kontrolnych aktywność ta stanowiła $12,0 \%$, a po dodaniu ekstraktu woskowego wzrosła 3-krotnie i przy stężeniu $10 \mu \mathrm{g} / \mathrm{g}$ wyniosła $36,1 \%$, natomiast przy stężeniu $100 \mu \mathrm{g} / \mathrm{g}$ osiągnęła wartość 41,8\%. Aktywność p-C w kontroli stanowiła $37,2 \%-4 \mathrm{~h}$ rejestracji, dodanie ekstraktu woskowego o niższym stężeniu spowodowało wzrost czasu trwania tej aktywności do $63,9 \%$, a w przypadku wyższego stężenia do 58,2\% (tab. 4). Ekstrakty woskowe spowodowały również wydłużenie czasu do pierwszego nakłucia, skróciły czas trwania pierwszej aktywności p-C oraz zwiększyły jej częstotliwość (tab. 5). 
$\mathrm{Na}$ pożywkach $\mathrm{z}$ ekstraktami woskowymi z genotypu RAH 366 następował spadek procentowego udziału aktywności związanej z obecnością sztyletów mszyc na powierzchni pożywki i aktywnym pobieraniem płynów $\mathrm{Z}$ diety. $\mathrm{Z}$ kolei wzrost procentowego udziału odnotowano dla aktywności p-C oraz p-E2 (tab. 4). Dla aktywności p-E1 obserwowano spadek procentowego udziału przy stężeniu $10 \mu \mathrm{g} / \mathrm{g}$ i wzrost przy stężeniu $100 \mu \mathrm{g} / \mathrm{g}$. (tab. 4). Ekstrakty woskowe z genotypu RAH 366 powodowały również, że mszyce znaczne szybciej dokonywały pierwszych nakłuć, wydłużały czas ich trwania oraz przyczyniły się do spadku ich częstotliwości (tab. 5).

Uzyskane wyniki wskazują, że woski epikutykularne pełnią istotną rolę $\mathrm{w}$ interakcjach mszyce-pszenżyto. Niezwykle cenne w tych wzajemnych relacjach jest bogactwo komponentów woskowych. Kompozycja tych substancji zależy od gatunku, genotypu oraz fazy rozwojowej rośliny (Eigenbrode i Espelie 1995; Jetter i Schäffer 2001). Różnice $\mathrm{w}$ chemicznym składzie powierzchni roślin mogą być ściśle powiązane $\mathrm{z}$ odpornością na roślinożerców i wpływać na ich zachowanie podczas żerowania oraz wzrost i rozwój (Valkama i wsp. 2005; Lahtinen i wsp. 2006; Wójcicka i Leszczyński 2006; Wójcicka 2009). Ekstrakty wosków powierzchniowych z siewek Sorghum bicolar (L.) zwiększały ich akceptację przez larwy Locusta migratoria (L.) (Woodhead 1983). Heksanowe ekstrakty z powierzchni lipidowej odpornej odmiany ryżu deterentnie wpływały na Nilaparvata lungens (Stäl) (Woodhead i Padgham 1988). Mechaniczne usunięcie warstwy wosków epikutykularnych z młodych liści Eucaliptus globulus (Labill.) spowodowało, że stały się bardziej odpowiednie do żerowania i rozwoju Ctenarytaina spatulata (Taylor) i Glycaspis brimblecombei (More) (Brennan i Weinbaum 2001). Podczas badań nad genotypami pszenżyta ozimego różniącymi się stopniem pokrycia nalotem woskowym stwierdzono, że rośliny genotypów pokrytych silnym nalotem woskowym były w mniejszym stopniu akceptowane przez mszycę zbożową S. avenae, czeremchowo-zbożową $R$. padi oraz mszycę różano-trawową Metopolophium dirhodum (Walk.) w porównaniu do roślin genotypów pokrytych woskiem w niewielkim stopniu (Wójcicka i wsp. 2010b, 2011). W przypadku roślin woskowych stwierdzono również późno pojawiające się pierwsze nakłucia powierzchni roślin, krótszy okres pierwszej penetracji komórek epidermy i mezofilu oraz krótszy czas pobierania pokarmu (Wójcicka i wsp. 2010a; Wójcicka 2011). Gruba warstwa epikutykularnego wosku na roślinach pszenżyta znacznie wydłużała okres przedreprodukcyjny oraz obniżała płodność dzienną i całkowitą badanych gatunków mszyc (Wójcicka 2007).

Wyniki prezentowane w pracy wskazują, że chemiczne komponenty wosku epikutykularnego woskowego genotypu RAH 122 i słabo pokrytego woskiem genotypu RAH 366 pełnią ważną rolę w procesie żerowania obu badanych gatunków mszyc: zbożowej $S$. avenae i czeremchowo-zbożowej $R$. padi. Podsumowując, komponenty epikutykularnych wosków wyraźnie oddziaływają na zachowanie mszyc zbożowych podczas żerowania i mogą być użyte do znaczącego ograniczenia liczebności szkodliwych owadów.

\section{Wnioski / Conclusions}

1. Wiedza dotycząca wpływu wosków epikutykularnych pszenżyta ozimego na zachowanie roślinożernych owadów stanowi cenną informację w regulacji populacji roślinożerców w naturze.

2. Połączenie tej wiedzy $\mathrm{z}$ nowoczesną hodowlą roślin oraz najnowszymi osiągnięciami biotechnologii pozwoli na szybkie i skuteczne uzyskanie genotypów pszenżyta skutecznie zabezpieczających przed szkodliwością mszyc.

\section{Literatura / References}

Athukorala Y., Mazza G. 2010. Supercritical carbon dioxide and hexane extraction of wax from triticale straw: Content, composition and thermal properties. Industrial Crops and Products 31: 550-556.

Bargel H., Barthlott W., Koch K., Schreiber L., Neinhuis C. 2004. Plant cuticles: multifunctional interfaces between plant and environment. p. 171-194. In: „Evolution Plant Physiology” (A.R. Hemsley, I. Poole, eds). Academic Press, London, 492 pp.

Brennan E.B., Weinbaum S.A. 2001. Stylet penetration and survival of three psyllid species on adult leaves and 'waxy' and 'de-waxed' juvenile leaves of Eucalyptus globulus. Entomologia Experimentalis et Applicata 100: 355-363.

Cid M., Fereres A. 2010. Characterization of the probing and feeding behavior of Planococcus citri (Hemiptera: Pseudococcidae) on Grapevine. Annals of the Entomological Society of America 103: 404-417.

Eigenbrode S.D., Espelie K.E. 1995. Effect of plant epicuticular lipids on insect herbivores. Annual Review of Entomology 40: $171-194$.

Fernández V., Khaget M., Montero-Prado P., Heredia-Guerrero J., Liakopoulos G., Karabourniotis G., del Rio V., Domingez E., Tecchini I., Nerin C., Val J., Heredia A. 2011. New inisghts into the properties of pubescent surfaces the peach fruit (Prunus persica L.) as a model. Plant Physiology 156: 2098-2108.

Hilker M., Meiners T. 2011. Plants and insect eggs: How do they affect each other? Phytochemistry 72: 1612-1623.

Huang J., McAuslane H.J., Nuessly G.S. 2003. Effect of leaf surface extraction on palatability of romaine lettuce to Diabrotica balteata. Entomologia Experimentalis et Applicata 106: 227-234.

Huang F., Tjallingii W.F., Zhang P., Zhang J., Lu Y., Lin J. 2012. EPG waveform characteristics of solenopsis mealybug stylet penetration on cotton. Entomologia Experimentalis et Applicata 143: 47-54.

Jetter R., Schäffer S. 2001. Chemical composition of the Prunus laurocerasus leaf surface. Dynamic changes of the epicuticular wax film during leaf development. Plant Physiology 126: 1725-1737.

Koch K., Bhushan B., Barthlott W. 2009. Multifunctional surface structures of plants: An inspiration for biomimetics. Progress in Materials Science 54: 137-178. 
Lahtinen M., Kapari L., Haukioja E., Pihlaja K. 2006. Effect if increased contact of leaf surface flavonoids on the performance of mountain birch feeding sawflies vary for early and late season species. Chemoecology 16: 159-167.

Leszczyński B., Tjallingii W.F. 1994. Przewodnik do elektronicznej rejestracji penetracji owadów w tkankach roślin. Wydawnictwa Uczelniane WSRP w Siedlcach, 83 ss.

Mukhtar A., Damerow L., Blanke M. 2014. Non-invasive assessment of glossiness and polishing of the wax bloom of European plum. Postharvest Biology and Technology 87: 144-151.

Nam K.J., Hardie J. 2012. Host acceptance by aphids: Probing and larviposition behaviour of the bird cherry-oat, Rhopalosiphum padi on host and non-host plants. Journal of Insect Physiology 58: 660-668.

Ou S., Zhao J., Wang Y., Tian Y., Wang J. 2012. Preparation of octacosanol from filter mud produced after sugarcane juice clarification. LWT - Food Science and Technology 45: 295-298.

Prüm B., Seidel R., Bohn H.F., Speck T. 2012. Plant surface with cuticular folds are slippery for beetles. Journal of the Royal Society 9 (6): $127-135$.

Reina-Pinto J.J., Yephremov A. 2009. Surface lipids and plant defenses. Plant Physiology and Biochemistry 47: 540-549.

Rostás M., Ruf D., Zabka V. 2008. Plant surface wax affects parasitoid's response to host footprints. Naturwissenschaften 95: 997-1002.

Sauvion N., Charles H., Fabvay G., Rahbé Y. 2004. Effects of jackbean lectin (ConA) on the feeding behaviour and kinetics of intoxication of the pea aphid, Acyrthosiphon pisum. Entomologia Experimentalis et Applicata 110: 31-44.

Schoonhoven L.M., Jermy T., Van Loon J.J.A. 2006. Plant Chemistry: Endless Variety. Insect-Plant Biology. Oxford University Press, Chapter 4, Chapman \& Hall, London, UK: 49-86.

Städler E., Reifenrath K. 2009. Glucosinolates on the leaf surface perceived by insect herbivores: review of ambiguous results and new investigations. Phytochemical Reviews 8: 207-225.

Supapvanich S., Pimsaga J., Srisujan P. 2011. Physicochemical changes in fresh-cut wax apple Syzygium samarangenese (Blume) Merrill \& L. M. Perry during storage. Food Chemistry 127: 912-917.

Tjallingii W.F. 1994. Sieve element acceptance by aphids. European Journal of Entomology 91: 47-52.

Tjallingii W., Esch T.H. 1993. Fine structure of aphid stylet routes in plant tissues in correlation with EPG signals. Physiological Entomology 18: 317-328.

Valkama E., Koricheva J., Salminen J.-P., Helander M., Saloniemi I., Saikkonen K., Pihlaja K. 2005. Leaf surface traits: overlooked determinants of birch resistance to herbivores and foliar micro-fungi? Trees 19: 191-197.

Woodhead S. 1983. Surface chemistry of Sorghum bicolor and its importance in feeding by Locusta migratoria. Physiological Entomology 8: 345-352.

Woodhead S., Padgham D.E. 1988. The effect of plant surface characteristics on resistance of rice to the brown planthopper, Nilaparvata lugens. Entomologia Experimentalis et Applicata 47: 15-22.

Wójcicka A. 2007. Effect of triticale surface compounds on growth and development of cereal aphids. Aphids and Other Homopterous Insects 13: 191-197.

Wójcicka A. 2009. Wpływ woskowości genotypów pszenżyta ozimego na parametry populacyjne mszyc zbożowych. [Effect of waxes and waxless triticale genotypes on survival and fecundity of the cereal aphid species]. Progress in Plant Protection/Postępy w Ochronie Roślin 49 (1): 157-160.

Wójcicka A. 2011. Wpływ wosków powierzchniowych pszenżyta ozimego na elementy biologii mszycy czeremchowo-zbożowej. [Effect of surface waxes of winter triticale on the biology of bird cherry-oat aphid Rhopalosiphum padi]. Progress in Plant Protection/Postępy w Ochronie Roślin 51 (4): 1590-1594.

Wójcicka A., Leszczyński B. 2006. Effect of ear awns and waxes on triticale resistance towards the grain aphid Sitobion avenae (F.). Aphids and Other Homopterous Insects 12: 195-202.

Wójcicka A., Leszczyński B., Warzecha R. 2011. Wpływ metanolowych ekstraktów wosków powierzchniowych pszenżyta ozimego na mszycę różano-trawową M. dirhodum. [Effect of methanol surface waxes of the winter triticale on rose-grain aphid]. Progress in Plant Protection/Postępy w Ochronie Roślin 51 (4): 1595-1599.

Wójcicka A., Sempruch C., Łukasik I., Warzecha R. 2010a. Wpływ wosków powierzchniowych pszenżyta ozimego na zachowanie mszycy różano-trawowej $M$. dirhodum. [Effect of epicuticular waxes in the winter triticale on feeding behaviour of rose-grass aphid Metopolophium dirhodum]. Zeszyty Problemowe Postępów Nauk Rolniczych 556 (2): 503-511.

Wójcicka A., Sempruch C., Warzecha R. 2010b. Wpływ wosków powierzchniowych pszenżyta ozimego na wybór rośliny żywicielskiej przez mszyce zbożowe. [Effect of surface waxes of triticale on host selection by cereal aphids]. Progress in Plant Protection/Postępy w Ochronie Roślin 50 (2): 609-612.

Wu D., Zeng L., Zhou A., Xu Y. 2013. Effect of Solenopsis invicta (Hymenoptera: Formicidae) tending on the probing behavior of Phenacoccus solenopsis (Hemiptera: Pseudococcidae). Florida Entomologist 96 (4): 1343-1349.

Yin Y., Bi Y., Chen S., Li Y., Wang Y., Ge Y., Ding B., Li Y., Zhang Z. 2011. Chemical composition and antifungal activity of cuticular wax isolated from Asian pear fruit (cv. Pingguoli). Scientia Horticulturae 129 (4): 577-582.

Zhang G.Z., Ge F., Su J.W., Hu C.X. 2009. Electrical penetration graph (EPG) of feeding behavior of Aphis gossypii on resistant cotton plants grown under elevated O3 concentration. Plant Protection 35: 30-34. 